\title{
Feasibility of rhizobia conservation by liquid conditioners ${ }^{1}$
}

\author{
Viabilidade da conservação de rizóbios por condicionadores líquidos
}

\author{
Carla Regine Reges Silva e França ${ }^{2}$, Mario Andrade Lira Junior ${ }^{3 *}$, Márcia do Vale Barreto Figueiredo ${ }^{4}$, Newton \\ Pereira Stamford ${ }^{3}$ e Gláucia Alves e Silva ${ }^{3}$
}

\begin{abstract}
This paper evaluates the possible use of liquid preservation methods for rhizobia long term conservation under ambient temperature conditions. Saline solution (sterile distilled water $+\mathrm{NaCl}$ ), glycerol and carboxymethycellulose (CMC) were evaluated for preservation of Rhizobium tropici and Bradyrhizobium japonicum cultures up to 180 days and regarding their capacity to promote common bean (Phaseolus vulgaris [L.]) and soybean (Glycine max [L.]) nodulation. The total population was determined after $0 ; 1 ; 7 ; 15 ; 21 ; 30 ; 60 ; 90 ; 120 ; 150$ and 180 days of conservation and conserved bacteria were evaluated for symbiotic characteristics after 15, 60 and 120 days of conservation. Although there were significant species x conservation method interactions, both saline solution and CMC may be used for short storage terms, allowing the production of inoculant for field experiments, and its test for purity and concentration before field establishment. The utilized techniques have low cost and easier usage as inoculants, compared to the traditional turf-based products, and if determined feasible by further research it could be a low cost addition to the standard microbiological techniques, particularly as working culture preservation media.
\end{abstract}

Key words: Bradyrhizobium. Carboxymethycellulose. Glycerol. Preservation of bacterial cultures.

RESUMO - Neste trabalho foi avaliado o possível uso de métodos de preservação líquida para conservação de rizóbio ao longo do tempo, sob condições de temperatura ambiente. Solução salina (água destilada esterilizada $+\mathrm{NaCl}$ ), glicerol e carboximetilcelulose (CMC) foram avaliados visando à preservação de culturas de Rhizobium tropici e Bradyrhizobium japonicum por 180 dias e em relação a sua capacidade para promover a nodulação do feijão comum (Phaseolus vulgaris [L.]) e da soja (Glycine max [L.]). A população total foi determinada após $0 ; 1 ; 7 ; 15 ; 21 ; 30 ; 60 ; 90 ; 120 ; 150$ e 180 dias de conservação e, as bactérias conservadas foram avaliadas quanto as suas características simbióticas após 15, 60 e 120 dias de conservação. Embora tenham ocorrido interações significativas entre os métodos de conservação x espécies, a solução salina e o CMC podem ser usados por períodos curtos de armazenamento, permitindo a produção de inoculante para experimentos de campo e teste de pureza e concentração antes do seu estabelecimento em campo. As técnicas utilizadas têm custo baixo e uso mais prático do que as tradicionais formulações em base turfosa, e se determinada a viabilidade por meio de novas pesquisas, poderia ser uma adição de baixo custo para a padronização de técnicas microbiológicas, particularmente como meio de trabalho para preservação de culturas.

Palavras-chave: Bradyrhizobium. Carboximetilcelulose. Glicerol. Preservação de culturas bacterianas.

\footnotetext{
*Autor para correspondência

Recebido para publicação em 21/03/2012; aprovado em 28/03/2013

This paper is part of the MSc Dissertation of the first author submitted to Soil Science Graduate Program of the Universidade Federal Rural de Pernambuco

${ }^{2}$ Programa de Pós-Graduação em Ciência do Solo, Universidade Federal Rural de Pernambuco, Recife-PE, Braszil, carlaregine@ yahoo.com.br ${ }^{3}$ Departmento de Agronomia, Universidade Federal Rural de Pernambuco, Recife-PE, Brasil, mario.lira@depa.ufrpe.br, newtonps@depa.ufrpe. br, glau_alvesilva@yahoo.com.br

${ }^{4}$ Instituto Agronômico de Pernambuco, Recife-PE, Brasil, mbarreto@elogica.com.br
} 


\section{INTRODUCTION}

The development of appropriate methods to maintain the viability of cultures in a stable genetically form is highly important. Thus, the main goal of any method of preservation is to keep viability without the presence of contaminants for as long as possible, while not allowing or minimizing the occurrence of mutations or variability. Ideally it would also be accessible, easy to implement and low-cost (ROMEIRO, 2001).

The preserved microorganisms must be submitted to tests in order to prove the viability of the cultures at regular time intervals (NAGAI et al., 2005). Several methods are used for the preservation of bacterial cultures such as immersing in mineral oil; ordinary freezing or drying; preservation in vegetable organs; preservation in soil; in sterile distilled and pure water; in glycerol; in synthetic polymers; or in liquid nitrogen or lyophilization (CAMPOS et al., 2004; FERNANDES JÚNIOR et al., 2009; DENARDIN; FREIRE, 2000; TUMELERO; DENARDIN, 2008; VAN ELSAS et al., 2001).

Carboxymethycellulose (CMC) and glycerol are possible carrier materials which can be evaluated for rhizobia conditioners. CMC is a cellulose-derived ester, and a highly hygroscopic and viscous polymer, nontoxic to humans (SANZ et al., 2005). Glycerol is a cryoprotectant commonly used in freezing processes, which can be used as osmoregulator and liquid conditioner (CAMPOS et al., 2004).

Liquid media rhizobia conservation may also reduce cost and efforts for the maintenance of microbial germplasm active banks during biodiversity and rhizobial efficiency research projects, while helping the development of low cost and easier usage inoculants, compared to the traditional turf-based products. So the research on these formulations is of great interest.

This work aimed to evaluate the effectiveness of formulations on based $\mathrm{NaCl}$ (saline solution), $\mathrm{CMC}$ and glycerol as liquid conditioners, regarding their capacity to maintain viable cells and promote common bean (Phaseolus vulgaris [L.]) and soybean (Glycine $\max$ [L.]) nodulation.

\section{MATERIAL AND METHODS}

\section{Rhizobia strains and composition of liquid conditioners}

Four rhizobia strains from two genera were used in this study, with two Rhizobium tropici, SEMIA 4077 $(=$ CIAT899) and SEMIA 4080 (= PRF81), and two Bradyrhizobium japonicum, SEMIA 5079 (= CPAC15) and SEMIA 5080 (= CPAC7) strains recommended for commercial bean and soybean inoculants, respectively. All strains were obtained from the germplasm bank of FEPAGRO (Fundação Estadual de Pesquisa Agropecuária, Porto Alegre, RS - Brazil).

To create the liquid conditioners, sterile distilled water together with $1,000 \mathrm{mg} \mathrm{L}^{-1} \mathrm{NaCl}, 200,000 \mathrm{mg} \mathrm{L}^{-1}$ glycerol or 2,000 $\mathrm{mg} \mathrm{L}^{-1}$ CMC were independently prepared and transferred to bottles followed sterilization in an autoclave at $121{ }^{\circ} \mathrm{C}$ for 20 minutes at $101 \mathrm{kPa}$. These conditioners and concentrations were based on previous unpublished work by the authors, with the main goal of day-to-day use for short period storage.

\section{Growth conditions and storage}

The bacteria were grown at $28{ }^{\circ} \mathrm{C}$ for three (SEMIA 4077 and SEMIA 4080) or seven (SEMIA 5079 and SEMIA 5080) days on yeast extract mannitol (YEM) medium (VINCENT, 1970) on a rotary shaker at constant (120 oscillations per minute). After the growth period, $0.5 \mathrm{~mL}$ of cell suspension of each strain was transferred to $2 \mathrm{~mL}$ tubes with $1.5 \mathrm{~mL}$ of each conditioner. Afterwards, they were agitated by vortex for 15 seconds and colony-forming units (CFU) numbers were determined for time zero. Each formulation (conditioner + strain) was kept in room temperature until 180 days, as separate experiments.

\section{Survival rhizobia cells in different liquid conditioners based $\mathrm{NaCl}$, glycerol and $\mathrm{CMC}$}

Rhizobia survival was evaluated at $0 ; 1 ; 7 ; 15$; $21 ; 30 ; 60 ; 90 ; 120 ; 150$ and 180 days of storage at room ambient $\left(\mathrm{ca} .28^{\circ} \mathrm{C}\right)$. Three separate tubes of each formulation were used for 10 -fold serial dilutions. The counts were made by the drop plate method (MILES; MISRA, 1938) using $20 \mu \mathrm{L}$ aliquots of the dilutions $10^{-}$ ${ }^{5}$ to $10^{-10}$. CFU count was performed in the dilution that presented from 6 to 50 colonies per $20 \mu \mathrm{L}$ drop.

The data were subjected to analysis of variance (ANOVA) and regression analysis, where the bacterial population and time were considered dependent and independent variables, respectively.

\section{Pot experiment}

Six Leonard jars experiments were conducted to evaluate the symbiotic performance of the rhizobia strains in bean cv. Carioca and soybean cv. Sambaiba after 15; 60 and 120 days of conservation. Each experimental design was fully randomized with factorial arrangement $2 \times 4$ of two strains (SEMIA 4077 and SEMIA 4080 in the experiments with bean and SEMIA 5079 and SEMIA 5080 in the experiments with soybean) and four liquids conditioners (saline, glycerol, CMC and freshly grown bacteria), with 4 replications. 
The Leonard jars contained sand and nitrogen-free Norris nutrient solution (VINCENT, 1970). Seeds were surface disinfected by immersion in $96 \%$ alcohol for $1 \mathrm{~min}$ followed by $30,000 \mathrm{mg} \mathrm{L}^{-1}$ solution of commercial-grade sodium hypochlorite commercial for $1 \mathrm{~min}$ and ten rinses in sterile distilled water. Four days later four seedlings were transplanted per pot, with a thinning to two plants by pot after seven days.

At transplant, all seedlings were inoculated with one $\mathrm{ml}$ of bacterial broth. The fresh bacteria treatment consisted of newly cultivated bacteria, while the remaining were obtained from the conservation experiments. Fresh bacteria was cultivated close to the period of evaluation, by growth in $250 \mathrm{~mL}$ flasks containing $100 \mathrm{~mL}$ of YEM medium (VINCENT, 1970) on a rotary shaker at constant (120 oscillations per minute) and adjusted to $\mathrm{pH} 6.8$ for the period of 96 hours, a $\pm 28{ }^{\circ} \mathrm{C}$, with serial dilution to $10^{-6}$, while conserved treatments were obtained by pooling of the experimental material of the $10^{-6}$ bacteria. $\mathrm{ml}^{-1}$ level of the respective conservation experiment, not adjusted for the real population. In this was we evaluated simultaneously bacteria survival and effectiveness.

Each experiment was harvested 25 and 30 days after transplant for bean and soybean, respectively. The parameters measured were nodule number, nodule dry matter, shoot and root dry matter, concentration and content of $\mathrm{N}$ in shoot dry matter.

The data were evaluated by ANOVA and when appropriate the Tukey test, for conditioners and strain $\mathrm{x}$ conditioner interactions.

\section{RESULTS AND DISCUSSION}

\section{R. tropici and B. japonicum survival in different liquid conditioners}

$\mathrm{NaCl}$ (saline solution $1,000 \mathrm{mg} \mathrm{L}^{-1}$ ) was as effective as glycerol and CMC in maintaining SEMIA 4077 population between $3 \times 10^{7}$ and $10^{8}{\mathrm{cfu} \mathrm{mL}^{-1}}^{-1}$ throughout the experiment. With $\mathrm{NaCl}$ (saline solution $1,000 \mathrm{mg} \mathrm{L}^{-1}$ ), SEMIA 4080 had initial population of $10^{7} \mathrm{cfu} \mathrm{mL} \mathrm{m}^{-1}$ falling to $10^{4} \mathrm{cfu} \mathrm{mL}^{-1}$ in about 60 days, coming back to $10^{7} \mathrm{cfu} \mathrm{mL}^{-1}$ for 150 and 180 days of storage. The zero population observed at 90 and 120 days of storage must have occurred due to some experimental error. Glycerol-stored SEMIA 4080 lost viability after 21 days of evaluation, while with CMC it achieved initial population of $5 \times 10^{7} \mathrm{cfu} \mathrm{mL}^{-1}$, followed by a decrease to $10^{3} \mathrm{cfu} \mathrm{mL}^{-1}$ at 60 days, returning to the initial values at 120 days and after 150 days of storage all the bacteria were dead (Figure 1).
$\mathrm{NaCl}$ (saline solution $1,000 \mathrm{mg} \mathrm{L}^{-1}$ ) was more efficient in maintaining slow-growing rhizobia viability (Figure 1), with both SEMIA 5079 and SEMIA 5080 population being $10^{7} \mathrm{cfu} \mathrm{mL}^{-1}$ virtually unchanged throughout the evaluation period. Similar behavior was observed with CMC for SEMIA 5079, as initial

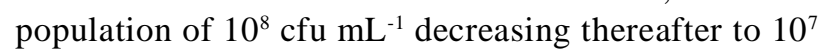
cfu $\mathrm{mL}^{-1}$ and stabilizing to the end of the experiment. Glycerol did not achieve comparable results, with continuous population loss from 30 days for both strains, although SEMIA 5080 had a strong population reduction over time than SEMIA 5079.

Overall, results were strongly strain-dependent. For SEMIA 4077 all studied conditioners showed satisfactory results, with a population around $10^{7} \mathrm{cfu} \mathrm{mL}^{-1}$ after 6 months of storage (Figura 1), while $\mathrm{NaCl}$ (saline solution $1,000 \mathrm{mg} \mathrm{L}^{-1}$ ) was the only effective conditioner for SEMIA 4080 and SEMIA 5080 strains until end of the experiment (180 days). For SEMIA 5079, $\mathrm{NaCl}$ (saline solution $1,000 \mathrm{mg} \mathrm{L}^{-1}$ ) or CMC were the most effective conditioners. At the same time, glycerol results were not satisfactory, since only SEMIA 4077 still had viable cells after 180 days.

\section{Symbiotic performance of rhizobia strains conserved with different liquid conditioners on bean and soybean}

Bean results are shown in Table 1 and Figure 2, with blank columns in Table 1 indicating significant interaction between strain and conditioner with the results presented in the Figure 2. All treatments effectively nodulated bean after conservation for 15,60 or 120 days (Table 1), however after 120 days of storage, only $\mathrm{NaCl}$ (saline solution) presented $\mathrm{N}$ concentration in shoot dry matter higher than those in the fresh bacteria. The lower results observed (shoot $\mathrm{N}$ content) for glycerol after 60 day storage agrees with the lower population observed on the earlier experiment.

In this experiment, SEMIA 4080 conserved with glycerol showed the lowest results for nodule number and dry matter and shoot dry matter, differing significantly from all conditioners studied. Despite the poor performance of glycerol for both strains, SEMIA 4080 showed a nodulation 30 times smaller than SEMIA 4077, with concomitant lower $\mathrm{N}$ concentration and shoot dry matter (Figure 2C, 2D and 2E).

$\mathrm{NaCl}$ was the most effective conditioner for SEMIA 4077, with nodule numbers $186 \%, 35 \%$ and $37 \%$; nodule dry matter $251 \%, 71 \%$ and $67 \%$ and shoot dry matter $120 \%, 40 \%$ and $160 \%$ higher than those of glycerol, CMC and fresh bacteria, respectively. Generally $\mathrm{NaCl}$ and $\mathrm{CMC}$ had the most promising results for the two strains of fast-growing strains. 
Figure 1 - Survival of strains Rhizobium tropici (SEMIA 4077 and SEMIA 4080) and Bradyrhizobium japonicum (SEMIA 5079 and 5080), conserved in room temperature with different liquid conditioners. Each point represents the mean of three replicates
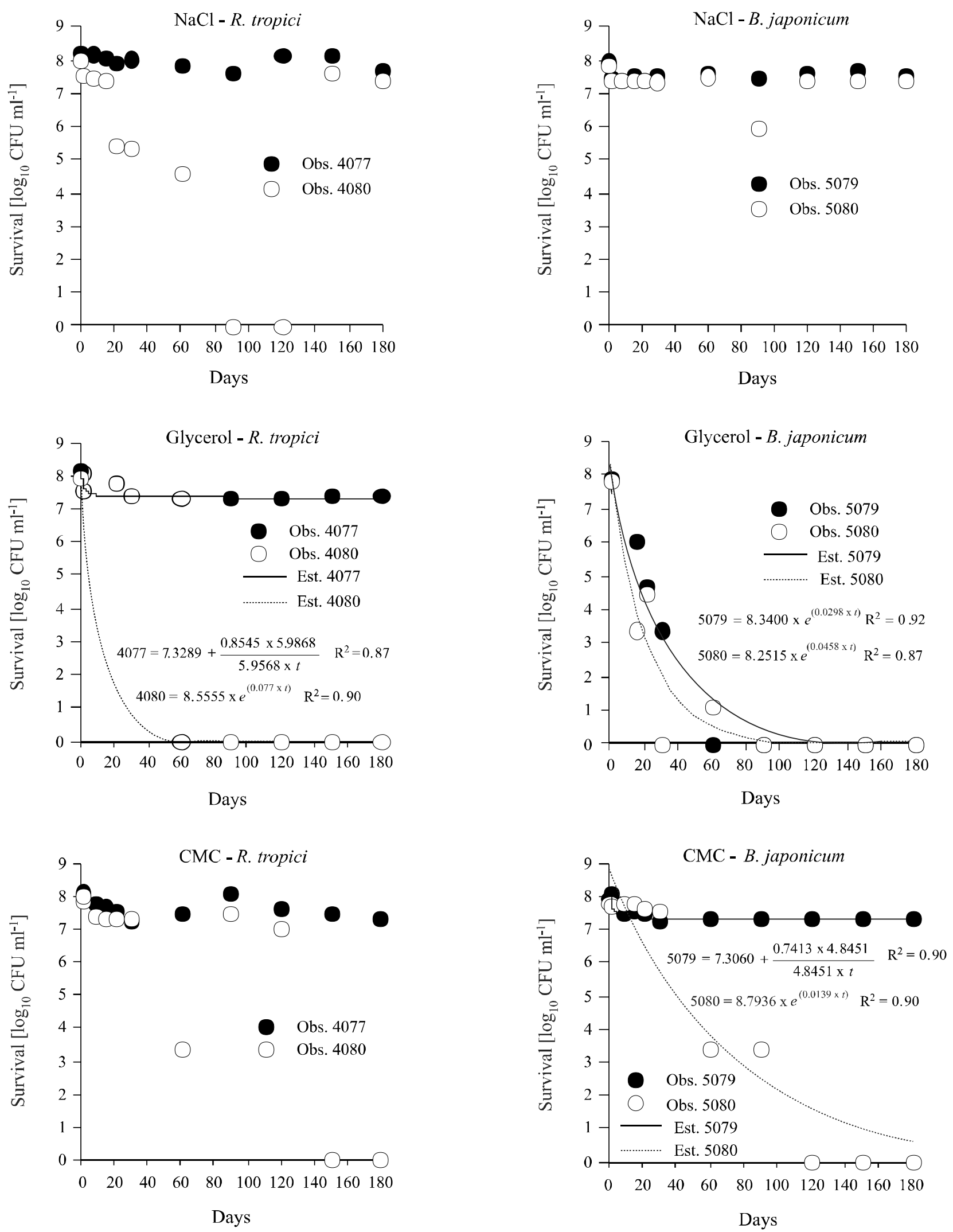
Table 1 - Effect of different liquids conditioners and strains on nodulation, shoot and root dry matter, concentration and content of $\mathrm{N}$ in shoot dry matter of plants of bean (Phaseolus vulgaris [L.]) after conservation for 15, 60 or 120 days of storage

\begin{tabular}{|c|c|c|c|c|c|c|}
\hline \multirow[t]{2}{*}{ Conditioners } & $\begin{array}{l}\text { Nodule } \\
\text { number }\end{array}$ & $\begin{array}{c}\text { Nodule } \\
\text { dry matter }\end{array}$ & $\begin{array}{c}\text { Shoot } \\
\text { dry matter }\end{array}$ & $\begin{array}{c}\text { Root } \\
\text { dry matter }\end{array}$ & $\begin{array}{c}\text { Shoot } \\
\text { N content }\end{array}$ & $\begin{array}{c}\text { Shoot } \\
\text { N concentration }\end{array}$ \\
\hline & Nodule pot ${ }^{-1}$ & \multicolumn{4}{|c|}{ 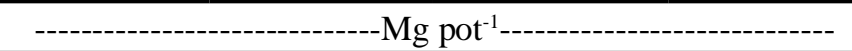 } & Dag kg-1 \\
\hline & \multicolumn{6}{|c|}{15 days of storage } \\
\hline Saline & & $174.63 \mathrm{a}^{1}$ & $534.67 \mathrm{a}$ & $291.00 \mathrm{~b}$ & $20.31 \mathrm{a}$ & \\
\hline Glycerol & & $79.88 \mathrm{~b}$ & $526.53 \mathrm{ab}$ & $393.46 \mathrm{a}$ & $11.35 \mathrm{~b}$ & \\
\hline $\mathrm{CMC}$ & & $117.50 \mathrm{~b}$ & $540.78 \mathrm{a}$ & $252.50 \mathrm{~b}$ & $15.11 \mathrm{ab}$ & \\
\hline Fresh bacteria & & $103.88 \mathrm{~b}$ & $353.41 \mathrm{~b}$ & $236.63 \mathrm{~b}$ & $12.37 \mathrm{ab}$ & \\
\hline \multirow[t]{2}{*}{$\mathrm{CV}(\%)$} & & 31.75 & 5.19 & 18.07 & 14.01 & \\
\hline & \multicolumn{6}{|c|}{60 days of storage } \\
\hline Saline & $269 \mathrm{a}$ & $249.11 \mathrm{a}$ & $889.88 \mathrm{a}$ & $444.19 \mathrm{a}$ & $32.43 \mathrm{ab}$ & $4.48 \mathrm{~b}$ \\
\hline Glycerol & $213 \mathrm{a}$ & $224.42 \mathrm{a}$ & $562.25 \mathrm{a}$ & $649.13 \mathrm{a}$ & $18.98 \mathrm{~b}$ & $4.32 \mathrm{~b}$ \\
\hline $\mathrm{CMC}$ & $213 \mathrm{a}$ & $297.96 \mathrm{a}$ & $866.75 \mathrm{a}$ & $560.94 \mathrm{a}$ & $36.69 \mathrm{a}$ & $4.97 \mathrm{a}$ \\
\hline Fresh bacteria & $179 \mathrm{a}$ & $222.39 \mathrm{a}$ & $912.00 \mathrm{a}$ & $570.49 \mathrm{a}$ & $24.24 \mathrm{ab}$ & $4.16 \mathrm{~b}$ \\
\hline \multirow[t]{2}{*}{$\mathrm{CV}(\%)$} & 49.21 & 9.87 & 33.84 & 5.45 & 13.69 & 35.97 \\
\hline & \multicolumn{6}{|c|}{120 days of storage } \\
\hline Saline & & & & $594.13 \mathrm{a}$ & $26.76 \mathrm{a}$ & $2.74 \mathrm{a}$ \\
\hline Glycerol & & & & $545.00 \mathrm{ab}$ & $9.61 \mathrm{~b}$ & $1.75 \mathrm{~b}$ \\
\hline CMC & & & & $632.69 \mathrm{a}$ & $19.08 \mathrm{a}$ & $2.31 \mathrm{ab}$ \\
\hline Fresh bacteria & & & & $421.92 \mathrm{~b}$ & $10.60 \mathrm{~b}$ & $1.84 \mathrm{~b}$ \\
\hline $\mathrm{CV}(\%)$ & & & & 4.19 & 15.42 & 26.80 \\
\hline
\end{tabular}

${ }^{1}$ Values of the same column for the same time of storage followed by same letter not are statistically different $(\mathrm{P}<0.05$ Tukey test $) ;{ }^{*}$ in the columns in blank there was significant interaction among conditioners at the $5 \%$ level of probability according to the F-test and the data are shown in the figure 2; when necessary were made the following transformations in the data: nodule number $-(x+1)$; nodule dry matter $-(x+1)$ or $\log (x+1)$; shoot and root dry matter - $\log (\mathrm{x})$; shoot $\mathrm{N}$ concentration $-\log (\mathrm{x})$ or $(\mathrm{x}) 4.1$ and shoot $\mathrm{N}$ content $-\log (\mathrm{x})$

After 15 days of storage, all treatments nodulated soybean, but with low nodule numbers (Table 2), with the highest values found with CMC which differed significantly from all other treatments. After conservation for 60 days, fresh bacteria showed nodulation 6 times greater than $\mathrm{NaCl}$ (saline) and $\mathrm{CMC}$, but there was no significant differences for shoot nitrogen content between fresh bacteria and CMC, although higher values were observed for fresh bacteria. Overall soybean nodulation (Table 2) was much lower than observed for bean plants (Table 1 and Figure 1).

Bacterial survival data after 180 days storage indicated that the conditioners showed a different capacity to maintain survival, with $\mathrm{NaCl}$ being more efficient in maintaining viability of slow-growing rhizobia (SEMIA 5079 and SEMIA 5080) (Figure 1). With this conditioner, SEMIA 5079 population remained virtually unchanged throughout the evaluation period at $10^{7} \mathrm{cfu} \mathrm{mL}^{-1}$. This was also observed with CMC, as initial population of $10^{8} \mathrm{cfu} \mathrm{mL}^{-1}$ decreasing thereafter to $10^{7} \mathrm{cfu} \mathrm{mL}^{-1}$ until the end of the experiment.

Albareda et al. (2008) have shown a population higher than $10^{9}$ viable cells $\mathrm{mL}^{-1}$ of $\mathrm{SMH} 12$ and USDA110 strains during 3 months of storage, with their best liquid formulations, while Tittabutr et al. (2007) working with various liquid formulations amended with different polymeric additives, have obtained bacterial densities higher than $10^{8}$ cells $\mathrm{mL}^{-1}$ of rhizobia strains after 6 months of storage. Both papers found cell survival was also dependent on rhizobia strain, which also happened in our results. According to studies conducted by Crist et al. (1984) slow-growing rhizobia survive longer than fast-growing rhizobia in liquid and peat-based inoculants and in the soil, which partly agrees with our result. 
Figure 2 - Symbiotic performance of bean (Phaseolus vulgaris [L.]) inoculated with the strains of Rhizobium tropici (SEMIA 4077 and SEMIA 4080), conserved by different liquids conditioners after 15 and 120 days of storage. A - Nodules number after 15 days of storage; B - Concentration of $\mathrm{N}$ in shoot dry matter after 15 days; C - Nodules number after 120 days of storage; D - Nodules dry matter after 120 days of storage; E - Shoot dry matter after 120 days of storage. Letters lower case and upper case compare strains and conditioners, respectively. Means followed by same letter not are statistically different $(\mathrm{P}<0.05$ Tukey test)
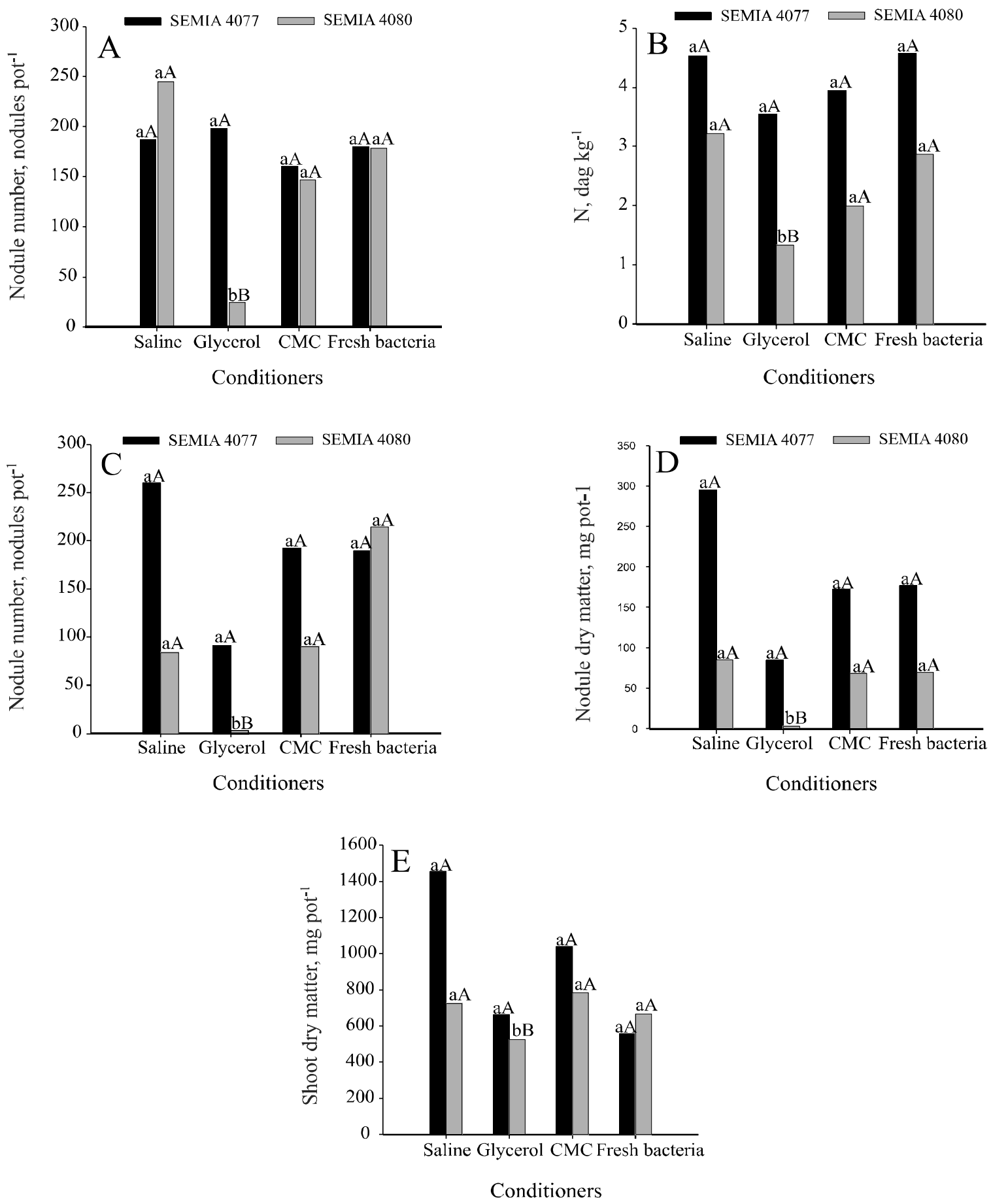

Few studies in the literature compare the survival of different rhizobia strains for long periods.

Moreover, these usually evaluate a single method of conservation such as in Cris et al. (1984), which 
Table 2 - Effect of the different liquids conditioners on nodulation, production of shoot and root dry matter, concentration and content of $\mathrm{N}$ in shoot dry matter of plants of the soybean (Glycine max [ L.]) after the conservation of the strains by 15; 60 or 120 days of storage

\begin{tabular}{|c|c|c|c|c|c|c|}
\hline Conditioners & $\begin{array}{l}\text { Nodule } \\
\text { number }\end{array}$ & $\begin{array}{c}\text { Nodule dry } \\
\text { matter }\end{array}$ & $\begin{array}{c}\text { Shoot dry } \\
\text { matter }\end{array}$ & $\begin{array}{l}\text { Root dry } \\
\text { matter }\end{array}$ & $\begin{array}{c}\text { Shoot N } \\
\text { content }\end{array}$ & $\begin{array}{c}\text { Shoot N } \\
\text { concentration }\end{array}$ \\
\hline & Nodule pot ${ }^{-1}$ & \multicolumn{4}{|c|}{$\mathrm{Mg} \mathrm{pot}^{-1}$} & $\mathrm{Dag} \mathrm{kg}^{-1}$ \\
\hline & \multicolumn{6}{|c|}{15 days of storage } \\
\hline Saline & $3 b^{1}$ & $13.80 \mathrm{ab}$ & $557.00 \mathrm{a}$ & $469.50 \mathrm{a}$ & $10.73 \mathrm{a}$ & $1.91 \mathrm{a}$ \\
\hline Glycerol & $2 \mathrm{bc}$ & $4.36 \mathrm{bc}$ & $552.00 \mathrm{a}$ & $526.75 \mathrm{a}$ & $10.07 \mathrm{a}$ & $1.83 \mathrm{a}$ \\
\hline $\mathrm{CMC}$ & $9 \mathrm{a}$ & $20.08 \mathrm{a}$ & $608.50 \mathrm{a}$ & $525.88 \mathrm{a}$ & $11.19 \mathrm{a}$ & $1.85 \mathrm{a}$ \\
\hline Fresh bacteria & $1 \mathrm{c}$ & $1.81 \mathrm{c}$ & $611.00 \mathrm{a}$ & $513.50 \mathrm{a}$ & $11.96 \mathrm{a}$ & $1.95 \mathrm{a}$ \\
\hline \multirow[t]{2}{*}{$\mathrm{CV}(\%)$} & 24.25 & 40.59 & 15.99 & 12.32 & 19.27 & 8.92 \\
\hline & \multicolumn{6}{|c|}{60 days of storage } \\
\hline Saline & $2 b$ & $1.81 \mathrm{~b}$ & $254.38 \mathrm{a}$ & $270.41 \mathrm{a}$ & $5.77 \mathrm{a}$ & $2.30 \mathrm{~b}$ \\
\hline Glycerol & - & - & $286.81 \mathrm{a}$ & $314.43 \mathrm{a}$ & $6.28 \mathrm{a}$ & $2.22 \mathrm{~b}$ \\
\hline CMC & $2 b$ & $5.46 \mathrm{ab}$ & $279.80 \mathrm{a}$ & $396.65 \mathrm{a}$ & $6.53 \mathrm{a}$ & $2.37 \mathrm{ab}$ \\
\hline Fresh bacteria & $12 \mathrm{a}$ & $20.35 \mathrm{a}$ & $291.92 \mathrm{a}$ & $285.33 \mathrm{a}$ & $8.63 \mathrm{a}$ & $3.00 \mathrm{a}$ \\
\hline \multirow[t]{2}{*}{$\mathrm{CV}(\%)$} & 50.25 & 45.23 & 6.75 & 5.11 & 24.45 & 18.81 \\
\hline & \multicolumn{6}{|c|}{120 days of storage } \\
\hline Saline & - & - & $1164.63 \mathrm{a}$ & $463.50 \mathrm{a}$ & $20.45 \mathrm{a}$ & $1.68 \mathrm{a}$ \\
\hline Glycerol & - & - & $1179.25 \mathrm{a}$ & $473.25 \mathrm{a}$ & $16.03 \mathrm{a}$ & $1.33 \mathrm{a}$ \\
\hline $\mathrm{CMC}$ & - & - & $1256.50 \mathrm{a}$ & $492.25 \mathrm{a}$ & $20.48 \mathrm{a}$ & $1.50 \mathrm{a}$ \\
\hline Fresh bacteria & - & - & $1238.04 \mathrm{a}$ & $472.50 \mathrm{a}$ & $22.20 \mathrm{a}$ & $1.79 \mathrm{a}$ \\
\hline $\mathrm{CV}(\%)$ & & & 27.24 & 27.36 & 40.20 & 48.31 \\
\hline
\end{tabular}

${ }^{1}$ Values of the same column for the same time of storage followed by same letter not are statistically different $(\mathrm{P}<0.05$ Tukey test); when necessary were made the following transformations in the data: nodule number $-\log (\mathrm{x}+1)$ or square root $(\mathrm{x}+1)$ or $(\mathrm{x}+1)-4.8$; nodule dry matter $-\log (\mathrm{x}+1)$ or square root $(x+1)$ or $(x+1)-4.6$; shoot and root dry matter and concentration and content of $N$ in shoot dry matter $-\log (x)$

evaluated preservation of various strains then classified as $R$. japonicum, $R$. meliloti, $R$. trifolii and Rhizobium cowpea group in water suspension, verified an initial increase in the population strains of slow-growing bacteria of $10^{5}$ to $10^{7} \mathrm{cfu} \mathrm{mL}^{-1}$, keeping this population level by one year, while the fast-growing strains lost viability in less of two weeks, both in pure water and buffer solutions of phosphate or sulfate of magnesia. Other authors studying survival of strain B323 of $R$. meliloti (Sinorhizobium meliloti) in demineralized water and different buffers, observed a constant decline in cell numbers during the storage in water and phosphate buffer in pH 5.5 arriving at zero in 10 months of storage (BOIARDI; MORENI; GALAR., 1988).

The results presented in this study show that $\mathrm{NaCl}$ and $\mathrm{CMC}$ have higher potential of use as conservant for the bacterial strains studied, but the strain $\mathrm{x}$ conservant interaction needs to be evaluated.
Promising results for CMC were also verified by Fernandes Júnior et al. (2009) evaluating CMC and starch blends as carrier materials of rhizobia inoculants regarding their capacity to maintain viable cells and promote cowpea nodulation. These authors observed that the $\mathrm{CMC} /$ starch polymer blends are efficient carriers to rhizobia inoculants for up to 165 days of storage, when mixed with $\mathrm{MgO}\left(10,000 \mathrm{mg} \mathrm{L}^{-1}\right)$.

Studies such as those developed in this work may allow product development of low cost, practical and also allow storage at room temperature, making it of great importance to obtain new formulations that can act efficiently as bacterial conditioners. However, despite of $\mathrm{NaCl}$ and $\mathrm{CMC}$ potential for use, the existence of interaction with the different strains indicates the necessity of study with higher genotype representatively before his recommendation for use as a long-term conditioner. 


\section{CONCLUSIONS}

$1 . \mathrm{NaCl}$ (saline solution) and $\mathrm{CMC}$ have shown potential for long-term strain storage under ambient temperature, but the interaction with the preserved strain needs better understanding;

2. Strain (genera or species) x conditioner interaction does not break down in a simple growth speed line, indicating other factors are in play on this behalf;

3.Short-period storage for both $\mathrm{NaCl}$ (saline solution) and $\mathrm{CMC}$ did not show significant interaction with strains, indicating both methods could be used for short storage terms, allowing the production of inoculant for field experiments, and its test for purity and concentration before field establishment.

\section{ACKNOWLEDGMENTS}

We thank Coordenação de Aperfeiçoamento de Pessoal de Nivel Superior - CAPES, for student and post-doctoral fellowships for the first and fifth authors and Conselho Nacional de Desenvolvimento Científico e Tecnológico - CNPq for research fellowship of the second, third and fourth authors. The work was partially financed by CNPq Grants 477708/2006-4 and 574831/2008-8 and FACEPE Grant APQ-1118-5.01/08.

\section{REFERENCES}

ALBAREDA, M. et al. Alternatives to peat as a carrier for rhizobia inoculants: Solid and liquid formulations. Soil Biology and Biochemistry, v. 40, n. 11, p. 2771-2779, 2008.

BOIARDI, J. L.; MORENI, N.; GALAR, M. L. Survival and infectivity of a Rhizobium meliloti strain maintained in water and buffer suspensions. Journal of Applied Bacteriology, v. 65, n. 3 , p. $189-193,1988$.
CAMPOS, A. K. et al. Predatory activity, radial growth and esporulation of nematode-trapping fungus Monacrosporium spp, submitted to cryopreservation. Ciência Rural, v. 34, n. 2, p. 465-469, 2004. (in Portuguese, with abstract in English).

CRIST, D. K. et al. Preservation of Rhizobium viability and symbiotic infectivity by suspension in water. Applied and Environmental Microbiology, v. 47, n. 5, p. 895-900, 1984.

DENARDIN, N. D.; FREIRE, J. R. J. Assessment of polymers for the formulation of legume inoculants, World Journal of Microbiology and Biotechnology, v. 16, n. 3, p. 215-217, 2000.

FERNANDES JÚNIOR, P. I. et al. Polymers as carriers for rhizobia inoculant formulations. Pesquisa Agropecuária Brasileira, v. 44, n. 9, p. 1184-1190, 2009.

MILES, A. A.; MISRA, S. S. The estimation of the bacterial power of the blood. Journal of Hygiene, v. 38, n. 6, p. 732749, 1938.

NAGAI, T. et al. Evaluation of preservation techniques of microorganism resources in the MAFF Genebank. JARQ: Japan Agricultural Research Quarterly, v. 39, n. 1, p. 1927,2005

ROMEIRO, R. S. Methods in Plant Bacteriology. Viçosa, MG: UFV, 2001. 279 p. SANZ, T. et al. Thermogelation properties of methylcellulose (MC) and their effect on a batter formula. Food Hydrocolloids, v. 19, n. 1, p. 141-147, 2005.

TITTABUTR, P. et al. Growth, survival and field performance of Bradyrhizobia liquid inoculant formulations with polymeric additives. Science Asia, v. 33, n. 1, p. 69-77, 2007.

TUMELERO, A. I.; DENARDIN, N. D. Formulation with polymers for the Pectobacterium atrosepticum and Ralstonia solanacearum. Summa Phytopathologica, v. 34, n. 1, p. 5861, 2008.

VAN ELSAS, J. D. et al. Effects of ecological factors on the survival and physiology of Ralstonia solanacearum bv.2 in irrigation water. Canadian Journal of Microbiology, v. 47, n. 9, p. 842-854, 2001.

VINCENT, J. M. A manual for the pratical study of rootnodule bacteria. Oxford: Blackwell Scientific. 1970. 164 p. (International Biological Programme Handbook, 15). 